\title{
Adam Cybulski
}

Uniwersytet Łódzki

\section{Dezorientacja, nadmiar, cytat O postmodernistycznym kodzie w filmach Leosa Caraksa}

Filmowa twórczość Leosa Caraksa, której trzon stanowi pięć realizacji pełnometrażowych z lat 1984-2012, znamionuje dwukodowe scalanie przekazów należacych do popkultury i kultury wysokiej, hybrydyzacja gatunkowa, estetyzacja świata przedstawionego, w końcu - posługiwanie się intertekstualnościa, czyli odwoływanie się do tego, co wcześniej zrodziła X Muza, tak w okresie klasycznym, jak i modernistycznym. Największe zainteresowanie krytyki wzbudziły jego wczesne utwory, Chtopak spotyka dziewczyne (Boy Meets Girl, 1984) oraz Zła krew (Mauvais sang, 1986), które w połowie lat osiemdziesiątych były chętnie określane mianem „neobarokowych” i stawiane obok ówczesnych dzieł Luca Bessona i Jean-Jacques'a Beineiksa. Wpisywanie twórczości Caraksa w ramy filmowego postmodernizmu z całą pewnością budzi mniejsze kontrowersje niż sam termin i próby jego zdefiniowania.

Na problemy związane z tym pojęciem zwraca uwage m.in. Dominika Oramus. W książce $O$ pomieszaniu gatunków: Science fiction a postmodernizm stwierdza, że trzy dekady temu chętnie opisywano ponowoczesny charakter globalnej kultury, co zaowocowało licznymi tekstami oferujacymi różne definicje tego nowego, nieokreślonego zjawiska w sztuce i rzeczywistości społecznej. „Starający się opisać postmodernizm kilka dekad temu krytycy zamiast formułować słownikowe definicje, często wymieniali jedynie jego symptomy i objawy"1. Przywołuje ona rozważania Fredrica Jamesona z kanonicznego eseju Postmodernizm $i$ społeczeństwo konsumpcyjne, w którym amerykański socjolog określał omawiany fenomen jako rezultat postindustrialnego stanu społeczeństwa kapitalistycznego ${ }^{2}$, a także utożsamiał go z przeczuciem nadchodzącego końca przejawów życia społecznego, takich jak sztuka czy ideologie ${ }^{3}$.

${ }^{1}$ Dominika Oramus, O pomieszaniu gatunków: Science fiction a postmodernizm, Warszawa 2010, s. 9.

${ }^{2}$ Fredric Jameson, Postmodernizm i społeczeństwo konsumpcyjne, przeł. Przemysław Czapliński, [w:] Postmodernizm. Antologia przektadów, red. Ryszard Nycz, Kraków 1996, s. 190.

${ }^{3}$ D. Oramus, op. cit., s. 9. 
Autor Archeologii przyszłości konstatuje również, iż proces przejścia od modernistycznej wyjątkowości do postmodernistycznej kultury przetwarzania wiąże się z tzw. „śmiercią podmiotu”, czyli z końcem indywidualizmu jako takiego ${ }^{4}$. Jameson kulturę ponowoczesną wiążę nie tylko z zanikiem podmiotowości, ale również z absencja głębi w sztuce, pseudowydarzeniami, pastiszem, brakiem poczucia historii, tak osobistej, jak i przeszłości cywilizacji w ogóle ${ }^{5}$. „Oto cały nasz współczesny system społeczny zaczą stopniowo tracić zdolność przechowywania przeszłości, żyjąc w wiecznej teraźniejszości i wiecznej zmianie, wymazującej te rodzaje tradycji, które wcześniejsze formacje społeczne musiały

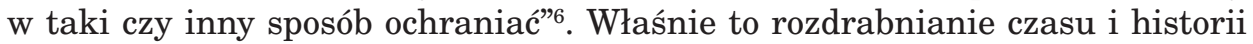
na „serie wiecznych «teraz»" jest według niego symptomatyczne dla omawianego procesu ewolucji modernizmu w postmodernizm. Badacz zaznacza jednocześnie, że skoro ten drugi model, którego początkiem były lata sześćdziesiąte, uderzał w kulture nowoczesna - w dzieła Igora Strawińskiego, Jamesa Joyce'a czy Marcela Prousta - jako we wrogi establishment, uświęcone pamiątki przeszłości, form postmodernizmu powinno być tyle, ile było postaci modernizmu klasycznego. Konstatuje jednak, że w żadnym stopniu monitorowanie takich ewentualnych analogii nie ułatwia zdefiniowania postmodernizmu jako zjawiska spójnego i zamkniętego ${ }^{8}$, przeciwnie - jak zauważa Jean-François Lyotard, kulture ponowoczesna w dużej mierze charakteryzuje fragmentaryczność i niepełność każdego przekazu9.

Francuski filozof, który utożsamił ten paradygmat $\mathrm{z}$ utratą wiary w wielkie opowieści, w eseju Odpowiedź na pytanie: co to jest postmodernizm, przytaczając myśl Albrechta Wellmera, bada przyczyny tego „pokawałkowania kultury” i odizolowania jej od życia, a za Jürgenem Habermasem akcentuje „sens pozbawiony wzniosłości” oraz „formę pozbawioną struktury”, cechujące klęskę sztuki nowoczesnej ${ }^{10}$. Śpieszę w tym miejscu z wyjaśnieniem - autor Kondycji ponowoczesnej określa postmodernizm jako wariant modernizmu: „Jest [postmodernizm - A.C.] z pewnościa częścia modernizmu. [...] Dzieło może być modernistyczne, o ile wcześniej było postmodernistyczne. Tak rozumiany postmodernizm nie jest modernizmem u swego kresu, lecz w momencie narodzin, który wciąż się pojawia"11.

Z kolei Ihab Hassan, teoretyk literatury badajacy omawiane zagadnienie, stwierdza, iż wizje świata ponowoczesnego tworzą: urbanizacja, dehumanizacja, technologizm, prymitywizm, erotyzm czy eksperymentalizm ${ }^{12}$. W eseju Toward a Concept of Postmodernism - w oparciu o porównanie do estetyki modernistycznej

\footnotetext{
${ }^{4}$ Por. F. Jameson, op. cit., s. 196.

${ }^{5}$ Por. D. Oramus, op. cit., s. 9.

${ }^{6}$ F. Jameson, op. cit., s. 212.

${ }^{7}$ Ibidem, s. 213.

${ }^{8}$ Ibidem, s. 191.

9 D. Oramus, op. cit., s. 10.

${ }^{10}$ Por. Jean-François Lyotard, Odpowiedż na pytanie: co to jest postmodernizm, przeł. Michał Paweł Markowski, [w:] Postmodernizm. Antologia..., s. 48-49.

${ }^{11}$ Ibidem, s. 58.

12 D. Oramus, op. cit., s. 10.
} 
- wymienia szereg wyznaczników właściwych kulturze postmodernistycznej. I tak, na przykład, w opozycji do modernistycznej hierarchii stoi postmodernistyczna anarchia, wobec syntezy - antyteza, obecności - brak, głębi - powierzchnia, paranoi - schizofrenia (koncept opisany skądinąd także przez Jamesona ${ }^{13}$ ), metafory - metonimia, metafizyki - ironia, zamkniętego dzieła - procesualność i performatywność, granic - intertekstualność, dystansu - udział ${ }^{14}$.

Niemożność klarownego objaśnienia postmodernistycznego systemu sygnifikacji oraz chętne wskazywanie na jego symptomy i twórców, których dzieła maja owe symptomy manifestować, przybliżałyby rozważania na temat tego zjawiska do definicji o charakterze zakresowo-synonimicznym ${ }^{15}$. Z jednej strony przywoływany Jameson wskazuje na pewien obszar kulturalny (m.in. na poezję Johna Ashbery'ego, muzykę Johna Cage'a, The Clash, Talking Heads, pop-art, Nouveau Roman czy kino „po Godardzie” ${ }^{16}$ ) pełniący rolę desygnatów, do których można odnieść interesujące mnie tutaj hasło. Z drugiej, postmodernizmem synonimicznie nazywa się często: ponowoczesność, schyłek sztuki, postmodernę, kulture pastiszu i parodii, przedłużenie modernizmu (Lyotard), ale i polemikę z nowoczesnością (Jameson). Takie uciekanie od podjęcia próby ukucia spójnej definicji tego fenomenu, a poprzestawanie na wyliczaniu kilku jego objawów nakreślonych na podstawie konfrontacji ze starszym realizmem oraz - w szczególności - modernizmem, wydaje sie jeszcze bardziej dostrzegalne na polu filmoznawczym.

\section{Postmodernizm w filmie}

Podobna metode komparatywną obiera Arkadiusz Lewicki w książce Sztuczne światy: Postmodernizm $w$ filmie fabularnym. Autor już we wstęie zastanawia się, czy ma do czynienia z epoka literacka, prądem kulturowym czy też stanem współczesnego społeczeństwa ${ }^{17}$. Sam termin wydaje się skomplikowany, gdyż wymaga od badacza zdefiniowania modernizmu oraz ustalenia funkcji przedrostka post ${ }^{18}$. W wymownie zatytułowanym tekście Kłopoty $z$ postmodernizmem Stefan Morawski zakłada, że określenie modernizmu inaczej pojmowano w Stanach Zjednoczonych, a inaczej w Europie. W pierwszym przypadku pojęcie to wiązało się $\mathrm{z}$,triumfami cywilizacji naukowo-technologicznej w ramach wysoko rozwiniętego industrializmu oraz $\mathrm{z}$ hierarchicznie zorganizowana, biurokratyczna [...] struktura społeczną"19. W Europie natomiast modernizm utożsamiano z takimi nurtami w sztuce, jak secesja, symbolizm oraz

${ }^{13}$ Por. F. Jameson, op. cit., s. 183.

${ }^{14}$ Por. Ihab Hassan, Toward a Concept of Postmodernism, [w:] The Postmodern Turn: Essays in Postmodern Theory and Culture, ed. I. Hassan, Columbus 1987.

15 Por. Piotr Żmigrodzki, Wprowadzenie do leksykografii polskiej, Katowice 2003, s. 81.

${ }^{16}$ Por. F. Jameson, op. cit., s. 190-191.

${ }^{17}$ Por. Arkadiusz Lewicki, Sztuczne światy: Postmodernizm w filmie fabularnym, Wrocław 2007, s. 5 .

${ }^{18}$ Ibidem, s. 6.

${ }^{19}$ Stefan Morawski, Kłopoty z postmodernizmem, „Kino” 1991, nr 2, s. 17. 
ekspresjonizm, w których upatrywano wzorcowych przejawów nowoczesnego poglądu na świat ${ }^{20}$. Skoro czymś zagadkowym pozostaje filmowy postmodernizm, należy przyjrzeć się - kwestionowanym przez przedstawicieli tego nurtu - realizacjom z kodem modernistycznym; z kolei, aby osiagnąc większą zrozumiałość w tym obszarze wypada omówić pokrótce, negowane przez modernizm, kino klasyczne $\mathrm{z}$ realistycznym systemem sygnifikacji. Taka droge obiera Lewicki, zestawiając ze soba trzy główne paradygmaty kulturowe dominujące we współczesnej sztuce. W swoich obserwacjach, przypominających skądinąd trójpolowy podział eseju Lyotarda czy konfrontowanie wyznaczników konkretnych paradygmatów przez Hassana, wyróżnia kilka kryteriów ułatwiających dokonanie rozróżnienia pomiędzy realizmem, modernizmem a postmodernizmem.

W kodzie realistycznym forma przekazu byłaby przezroczysta niczym szyba, dominantą interpretacyjna - fabuła, charakterystyczny miałby być zewnętrzny typ świata przedstawionego, w modelu komunikacyjnym dominowałby tekst, utwory wpisywałyby się w model kultury popularnej, w oglądzie rzeczywistości dominowałby racjonalizm, a znamienny byłby obojętny stosunek do tradycji. Natomiast w modelu modernistycznym przekaz byłby zaburzany przez zniekształcające lustro, dominantą interpretacyjna powinna być forma, symptomatyczny byłby wewnętrzny charakter świata przedstawionego, w modelu komunikacyjnym stroną dominujacca miałby być nadawca, teksty należałoby sytuować bliżej kultury elitarnej i wysokiej, irracjonalizm określałby sposób oglądu rzeczywistości, a stosunek do tradycji polegałby na jej odrzuceniu. I w końcu kod postmodernistyczny umiejscawia autor niejako między dwoma poprzednimi. Zatem system ten łączyłby przezroczystość i zaburzenia przekazu, dominanta interpretacyjna byłyby w nim tak forma, jak i fabuła, świat przedstawiony miałby sztuczny charakter, w modelu komunikacyjnym dominowałby odbiorca, dochodziłoby do integrowania kultury wysokiej z popkultura oraz wymieszania racjonalizmu $\mathrm{z}$ irracjonalizmem, w końcu istotna cecha byłoby odwoływanie się do przeszłości ${ }^{21}$, czego manifestacją jest intertekstualność. Badacz przypomina jednocześnie, iż powyższa charakterystykę traktować należy umownie jako uproszczony schemat. W istocie, bezrefleksyjne wpisanie takich egzemplifikacji realizmu, jak proza Karola Dickensa, obrazy Edwarda Hoppera czy filmowe realizacje Alfreda Hitchcocka, w ramy kultury popularnej mogłoby okazać się bezzasadne i krzywdzące. Kłopoty z określeniem, czym jest i jak wyglada realizacja postmodernistyczna wynika zapewne ze złożoności i różnorodności omawianego zjawiska oraz - jak pisze Aleksandra Drzal-Sierocka, przytaczając Lyotardowski „postmodernistyczny stan ducha” - z tego, iż filmowa postmodernę raczej sie „czuje” aniżeli „rozumie”22. W obliczu tych niejasności pomocne okaże się dokonanie krótkiej charakterystyki wyznaczników tegoż kodu, o których już pisali m.in. właśnie francuski filozof, Jameson czy Hassan, w kontekście kina.

\footnotetext{
${ }^{20}$ Ibidem.

${ }^{21}$ Por. A. Lewicki, op. cit., s. 68-69.

${ }^{22}$ Por. Aleksandra Drzał-Sierocka, Luc Besson: Uśmiechnięta twarz filmowego postmoderni$z m u$, Warszawa 2012, s. 23.
} 
Jednym z symptomów postmodernizmu jest niewątpliwie dwukodowość, czyli mieszanie w ramach jednego tekstu elementów charakterystycznych dla kultury wysokiej z przekazami popkultury. W filmowym postmodernizmie podział na jedną i druga w zasadzie traci rację bytu, gdyż w utworze spotykają się komponenty obu tych obszarów. Jameson we wspomnianym już eseju stwierdza: „Cechą [postmodernizmu - A.C.] jest [...] zanik kluczowych rozgraniczeń i przedziałów, a zwłaszcza rozmycie wcześniejszego rozróżnienia na kulturę wysoką i tak zwaną popularną"23. Przy okazji omawiania zanikajaccej opozycji elitarne-egalitarne, a także mieszania tego, co kojarzone $\mathrm{z}$ wyczuciem dobrego smaku z elementami właściwymi ludycznej rozrywce, wyróżnić należy przede wszystkim twórczość Petera Greenawaya, z jednej strony cytującego w swych filmach obrazy barokowych malarzy holenderskich (Rembrandta czy Jana Vermeera), z drugiej - posługujacego się powierzchowną fabułą budowaną na zbrodni, zdradzie i zemście. Warto jednocześnie przytoczyć w tym miejscu wattpliwości Tadeusza Miczki wobec używania terminu „dwukodowość”; obiekcja ta, jak sądzę, wydaje się jeszcze bardziej uzasadniona w kontekście współczesnego, coraz bardziej eklektycznego kina:

W rodzinie wolnych gier mieści się naprawdę bardzo dużo luźno ze soba powiązanych elementów tematycznych i stylistycznych. [...] Ona [intertekstualna gra - A.C.] niewątpliwie opiera się na wielokodowości. Artyści wprowadzaja do swoich dzieł „cytaty cytatów” (fragmenty tekstów cytowane już dawniej w charakterze kodów czy mitów rozpoznawczych) lub - jeśli można tak powiedzieć - symbole, metafory i metonimie cytatów z różnych obszarów kultury. W koncepcji dwukodowości mylny okazuje się przedrostek liczebnikowy ${ }^{24}$.

Kolejną cechą filmu postmodernistycznego jest przywołana powyżej intertekstualność, czyli - zgodnie z definicją Ryszarda Nycza - „kategoria obejmująca ten aspekt ogółu własności i relacji tekstu, który wskazuje na uzależnienie jego wytwarzania i odbioru od znajomości innych tekstów [...] przez uczestników procesu komunikacyjnego" ${ }^{25}$. Należy jednakowoż zaznaczyć, iż zjawisko to nie jest oczywiście wytworem filmowego postmodernizmu, a zostało jedynie przezeń „zaanektowane”. Morawski, powołując się na obserwacje Gérarda Genette'a z rozprawki Palimpsesty, zakłada, iż spośród gier między tekstami filmowy postmodernizm preferuje tzw. hipotekst. Koncepcja hipertekstualności mówi o trawestowaniu tekstu prototypowego, o aluzyjnym doń nawiązywaniu, o pastiszowym i parodystycznym przekształcaniu ${ }^{26}$. Istotnym warunkiem $\mathrm{w}$ grach intertekstualnych, polegających na nawiązaniach do

${ }^{23}$ F. Jameson, op. cit., s. 192.

${ }^{24}$ Tadeusz Miczka, Wielkie ŻARCIE i POSTmodernizm. O grach intertekstualnych $w$ kinie wspótczesnym, Katowice 1992, s. 78.

${ }^{25}$ Ryszard Nycz, Tekstowy świat. Poststrukturalizm a wiedza o literaturze, Kraków 2000, s. 83.

${ }^{26}$ Por. Stefan Morawski, Postmodernizm a kultura filmowa, „Kino” 1991, nr 3, s. 14. Genette zakłada istnienie pięciu kategorii transtekstualnych (dotyczących zależności między tekstami): intertekstualność, paratekstualność (relacja między tekstem właściwym a „paratekstem”, czyli np. posłowiem, przedmowa, wstępem itd.), metatekstualność (relacja-komentarz łącząca tekst z tym, do którego się odnosi), architekstualność (abstrakcyjny typ transtekstualności, polegający na wprowadzeniu do tekstu „niemej” wzmianki dotyczacej gatunku danego utworu), hipertekstualność. Por. Gérard Genette, Palimpsesty. Literatura drugiego stopnia, przeł. Aleksander Milecki, [w:] Wspótczesna teoria badań literackich za granica, red. Henryk Markiewicz, t. 4, cz. 2, Kraków 1992, s. 109-113. 
wcześniejszych dzieł, jest z jednej strony świadomość twórcy czyniącego taka referencję, z drugiej - kompetencje odbiorcze widza, który daną aluzję musi odczytać. Autor przytoczonego wyżej Wielkiego ŻARCIA..., za Rolandem Barthes'em [„«Ja» nie jest przedmiotem naiwnym, wcześniejszym od tekstu. [...] Ten podmiot, który zbliża się do tekstu, jest już sam wielością innych tekstów, kadrów nieskończonych lub dokładniej: utraconych (takich, których źródło zostało zapomniane) [...]"], zwraca uwage na celowość i swoista „uczciwość” intertekstualnego nawiązania, podkreślajacc, że postmodernista jest świadom swych artystycznych ograniczeń i godzi się na to, aby wyrazić się w dziele poprzez cytaty czy trawestacje, przy jednoczesnym podkreśleniu, iż posługuje się właśnie powtórzeniem ${ }^{27}$.

W paradygmat ten silnie wpisana jest również estetyzacja oraz stylistyka nadmiaru. Hasła te przywodzą na myśl - wspominany na samym początku neobarok, będacy zjawiskiem wyjątkowym we francuskim kinie lat osiemdziesiątych. Trzech reżyserów, Carax, Beineix oraz Besson, tworzyło w tym okresie filmy, dla których symptomatyczne były: pretekstowy charakter fabuł wyprowadzonych zazwyczaj ze schematów kina gatunkowego, obsesyjne estetyzowanie obrazu, eskapistyczny i niemimetyczny charakter, negowanie klasycznej psychologii bohaterów i przyczynowo-skutkowości opowiadania, dekoracyjny przesyt i scenograficzny nadmiar, posługiwanie sie językiem wideoklipowym, intertekstualne odniesienia, heterogeniczność stylistyczna, narracyjne unieważnianie głównych wątków fabularnych na rzecz wątków pobocznych, w końcu - akcentowanie obcości, pustki oraz skłonność do karykatury. Jednakowoż bogactwo formy nie jest domena jedynie neobarokowych Divy (1981), Betty (37으 le matin, 1985), Złej krwi czy Metra (Subway, 1985). Reżyserem kładącym duży nacisk na język jest również - wzmiankowany wcześniej - Greenaway. To niezwykle zaprojektowane mise-en-scène (lub - w zależności od filmu - mise-en-page $\left.{ }^{28}\right)$, bardziej niż anegdota, wydaje się być dominanta jego dzieł. Warto zaznaczyć, że estetyka nadmiaru formalnego (wraz z często towarzyszącymi jej odstępstwami od przezroczystej narracji i przyczynowo-skutkowości) jest właściwa twórcom - posługując się rozróżnieniem zaproponowanym przez Andrzeja Zalewskiego - nurtu postmodernizmu innowacyjnego ${ }^{29}$.

${ }^{27}$ Por. T. Miczka, op. cit., s. 90. Cyt. za Jonathan Culler, Presupozycje i intertekstualność, przeł. Katarzyna Rosner, „Pamiętnik Literacki” 1980, s. 3.

${ }^{28}$ W filmowym dorobku Greenawaya wyróżnić można zarówno filmy bardziej „klasyczne”, ze spójną diegezą oraz narracja jako taka, jak np. Brzuch architekta (The Belly of an Architect, 1987) czy Kucharz, złodziej, jego żona i jej kochanek (The Coook, the Thief, His Wife and Her Lover, 1989), jak i realizacje o silnych znamionach awangardy, w których reżyser posługuje się m.in. multiplikacją obrazu i narracja bazodanowa - do tych należą m.in.: Pillow Book (1996) czy Goltzius and the Pelican Company (2012).

${ }^{29}$ Zalewski, polemizujac z podziałem zaproponowanym przez Kristin Thompson i Davida Bordwella (na postmodernizm eksperymentalny i komercyjny), dokonał rozróżnienia filmowego postmodernizmu na nurt innowacyjny (w zakresie poszukiwań nowych rozwiązań narracyjnych oraz sposobów kształtowania lub destrukcji filmowych znaczeń) i nurt konserwatywny (innowacyjność ograniczająca się do konstrukcji rzeczywistości profilmowej). Por. Andrzej Zalewski, Strategiczna dezorientacja. Perypetie rozumu $w$ fabularnym filmie postmodernistycznym, Warszawa 1998, s. 11. 
Majac przed oczyma omówione powyżej właściwości, należy dojść do wniosku, iż filmowy postmodernizm bazuje na eklektyzmie i różnorodności, manifestujacych się nie tylko w ramach ogółu paradygmatu (rozmaitość stylów wielu reżyserów), ale także w obrębie pojedynczych realizacji. Pluralistyczne są wszakże hybrydy gatunkowe, integrowanie sztuki elitarnej z przekazami rozrywkowymi oraz intertekstualność. „Postmodernistyczna różnorodność oznacza nie tyle, że coś może być albo takie, albo takie, ale raczej - że to coś jest i takie, i takie jednocześnie"30. Filmowy postmodernizm to zatem pojęcie-worek, do którego wrzucić można niezliczoną liczbę realizacji, od parodii Mela Brooksa i autopastiszów Wesa Cravena, przez kinofilskie trawestacje Quentina Tarantino i Briana De Palmy, po wyszukane wizualnie, niekiedy nowatorskie, dzieła Davida Lyncha, Greenawaya czy neobarokowego tercetu. W takiej sytuacji pomocna okaże się typologia zaproponowana przez Lewickiego - wyróżnia on: postmodernizm popularny, właściwy oraz wysoki.

W postmodernizm popularny, ograniczajacy się głównie do integrowania przekazów właściwych kulturze masowej w obrębie jednego dzieła, wpisać należy głównie parodie. Bardzo przystępne nawiązania do kina rozrywkowego mogą być manifestowane na dwa sposoby. Pierwszy z nich polega na hiperbolizacji w utworze realistycznym schematów fabularnych lub na prowadzeniu gry z dobrze znanymi chwytami gatunkowymi. Druga metoda polega na bazowaniu na intertekstualności oraz kreowaniu deziluzyjności poprzez zabiegi autotematyczne ${ }^{31}$.

Właściwa odmiana tego systemu, podobnie jak wcześniejsza, opiera się w dużej mierze na interekstualności, jednak nie ogranicza się w tym zakresie tylko do kultury masowej czy kina realistycznego. Realizacje wyraźnie wykorzystuja matryce gatunkowe, ale bardzo silnie je trawestuja, tworzac dzięki temu specyficzny, autoteliczny paradygmat, jednocześnie często odwołujac się do tzw. kina wysokiego. Oprócz dzieł wspomnianego Tarantino przykładem posługiwania się takim językiem jest Ghost Dog: Droga samuraja (Ghost Dog: The Way of the Samurai, 1999) Jima Jarmuscha, hołdujacy kulturze japonskiej, nawiązujacy do kina Akiry Kurosawy (Rashômon, 1950) czy nowofalowej twórczości Seijuna Suzukiego [Namaszczony do zabijania (Koroshi no rakuin, 1967)]. W filmy właściwego postmodernizmu wliczona jest tak lektura naiwna, jak i domaganie się od twórcy widza kompetentnego ${ }^{32}$.

Ostatnia kategorię, postmodernizm wysoki, cechuje natomiast wyraźny rodowód kodu modernistycznego. Do tej kategorii należy zaliczyć realizacje innowacyjne, o znamionach awangardy, odbiegajace od stylu zerowego, poszukujące nowych rozwiązań narracyjnych czy sposobów konstruowania znaczeń ${ }^{33}$. Tego typu strategie można odnaleźć m.in. w filmach Davida Lyncha, Zagubionej autostradzie (Lost Highway, 1997) czy Mulholland Drive (Mulholland Dr., 2001). W przeciwieństwie do poprzednich dwóch odmian postmodernizm wysoki w wymiarze intertekstualności śmiało wykracza poza medium filmowe.

\footnotetext{
${ }^{30}$ A. Drzał-Sierocka, op. cit., s. 25.

${ }^{31}$ Por. A. Lewicki, op. cit., s. 133-154.

${ }^{32}$ Ibidem, s. 154-169.

${ }^{33}$ Ibidem, s. 111-133.
} 
Dzieła takie jak Zet $i$ dwa zera (A Zed and Two Noughts, 1985), Caravaggio (1986) czy The Limits of Control (2009) nawiązuja przede wszystkim do malarstwa. Inny przykład odwoływania się do tekstu spoza obszaru kina można odnaleźć w Truposzu (Dead Man, 1995), w granicach którego poetykę antywesternu połązył Jarmusch z aluzjami do twórczości Williama Blake’a. Warto również nadmienić, że dla tej odmiany symptomatyczne sa strategie intencjonalnej dezorientacji odbiorcy, opisane zajmująco przez Zalewskiego.

Warto w tym miejscu przywołać podział technik dezorientacyjnych zaproponowany przezeń w opracowaniu praktyk postmodernistycznego języka filmowego - Strategiczna dezorientacja: Perypetie rozumu $w$ fabularnym filmie postmodernistycznym. Pierwszą kategoria są techniki przedmiotowe, ściśle związane z rzeczywistościa profilmowa, mogące manifestować się $\mathrm{np}$. w konstruowaniu niezwykłych obiektów, scenerii czy też aparycji lub zachowań bohaterów ${ }^{34}$. Drugim typem sa natomiast techniki nieprzedmiotowe, które polski filmoznawca dzieli na demonstracyjne i narracyjne. Te pierwsze sa nadal zwiąane z sama diegeza, jednak na plan pierwszy wysuwaja się środki wyrazu. Innymi słowy, (nie)zwykłe obiekty i wydarzenia można zaprezentować w niecodzienny sposób, wywołujac tym samym konfuzję odbiorczą. Technika demonstracyjna intencjonalnie zakłóca bowiem czytelność przestrzeni. Natomiast w przypadku odmiany narracyjnej akcent $\mathrm{z}$ diegezy ( $\mathrm{z}$ obiektów, bohaterów etc.) przesuwa się na sam akt opowiadania, i polega na naruszeniu jego porządku ${ }^{35}$.

\section{2. (Post)modernistyczny debiut}

Pierwszy pełnometrażowy film Caraksa, Chtopak spotyka dziewczyne, otwierają niewyraźne, nocne obrazy Sekwany oraz towarzyszacy im, docierajaccy z komentarza ponadkadrowego, głos dziecka, flegmatycznie recytujaccego fragment inaugurujący powieść Louisa-Ferdinanda Céline'a Śmierć na kredyt: „I znowu jesteśmy sami. Wszystko to jest takie powolne, ociężałe, takie smutne. Wkrótce będę stary. I będzie wnet koniec"36. Przywołanie prologu tekstu kontrowersyjnego egzystencjalisty, już we wstępie debiutanckiego dzieła, wydaje się wykraczać poza puste zapożyczenie: dzisiejsza znajomość nieszablonowej twórczości Caraksa oraz jego niepokornego artystycznego usposobienia pozwala to zacytowanie Céline'a, uchodzącego w annałach literatury za enfant terrible, uznać za świadome nawiązanie pozatekstowe mające przysłużyć się w kreowaniu wizerunku młodego reżysera.

Chociaż poszczególne rozwiązania stylistyczne przywodzą na myśl język wczesnych, nowofalowych dzieł Godarda czy surrealistyczno-poetyckiego kina

\footnotetext{
${ }^{34}$ Por. A. Zalewski, op. cit., s. 17-24.

${ }^{35}$ Ibidem, s. 24-38.

${ }^{36}$ Carl-Johan Malmberg, Mitość od ostatniego spojrzenia, przeł. Piotr Kopański, „Film na Świecie" 1993, nr 2 (393), s. 35. Fragment powieści pochodzi z przekładu Juliana Stryjkowskiego. Louis-Ferdinand Céline, Śmierć na kredyt, Kraków 2004, s. 7.
} 
Jeana Cocteau ${ }^{37}$, intertekstualne odniesienia nie stanowia dominujacej techniki postmodernistycznej w Chtopak spotyka dziewczynę. Aby lepiej zrozumieć specyfike debiutanckiego utworu Francuza w kontekście filmowej ponowoczesności, warto przyjrzeć mu się w optyce technik dezorientacji opisanych przez Zalewskiego. Do dezorientacji nieprzedmiotowej o charakterze narracyjnym, zakłócającej opowiadanie filmowego czasu, należy zaliczyć scenę gry w elektryczny bilard, w której głównemu bohaterowi, Aleksowi, towarzyszy nieznajomy mężczyzna w średnim wieku. Akt ten rozgrywa się w zasadzie w ostatniej fazie filmu - widz wie tyle, że protagonista musi pospieszyć się, aby zdążyć na pociąg (przy jednoczesnym wrażeniu, iż dominujący do tej pory watek jego znajomości z Mireille został unieważniony). Tymczasem scena poświęcona bagatelnej rozrywce w dworcowym barze zajmuje aż pięć minut czasu ekranowego i zostaje dodatkowo wydłużona, w psychologiczno-percepcyjnym sensie, poprzez wykorzystanie długiego, statycznego ujęcia ${ }^{38}$. W tym miejscu narracja filmu posługuje się więc zabiegiem prolongaty: nieistotne $\mathrm{z}$ punktu widzenia rozwoju opowiadania wydarzenie zyskuje swoisty naddatek znaczeniowy dzięki przeznaczeniu na jego przedstawienie większej ilości czasu ekranowego oraz większej pieczołowitości formalnej niż w przypadku przedstawienia analogicznej sceny, o podobnej „wartości” fabularnej, przez kino stylu zerowego ${ }^{39}$.

Autor Strategicznej dezorientacji konstatuje, iż narracyjne techniki dezorientacji nie ograniczaja sie jedynie do „powolnego” i nietypowego czasowego zrytmizowania konkretnych sekwencji, ale moga być manifestowane poprzez niejasność powiązań między rozwijanymi fazami opowiadania ${ }^{40}$. Jedna z odmian takiej niejasności polega na nieczytelności „szczegółów zawartości i przebiegu faz, tworzacych np. filmowe zdarzenia, przy zrozumiałości co do generaliów"41. Innymi słowy, dezorientacja polega na zakłóceniu obrazu informacji czy danych pozwalajacych na identyfikacje faktu diegetycznego, przy generalnym jego rozpoznaniu. Egzemplifikacji takiej niejasności upatruje autor w zakończeniu debiutanckiego obrazu Caraksa, w którym reżyser zaproponował dwa warianty samobójstwa Mireille, ukochanej tytułowego bohatera. W pierwszej wersji Alex otwiera drzwi do mieszkania dziewczyny, przechodzi przez pokój, na podłodze którego znajduja się rozbryzgi krwi, i finalnie dobiega do umierającej samobójczyni. W drugim wariancie Mireille jeszcze żyje, gdy do mieszkania

${ }^{37}$ Wielu autorów piszaccych o wczesnym dorobku Caraksa zwraca uwage na nawiązania do stylu reżysera Krwi poety (Le Sang d'un poete, 1932), nie wypunktowując jednak podobieństw między dziełami obu twórców. W pierwszych filmach Carax od Cocteau zapożyczył - jak sądzę: eklektyzm stylistyczny, autotematyzm/autobiografizm, kreowanie osobliwych scenografii, deziluzyjność świata przedstawionego, skłonność do poetyckich metafor, zabieg przedstawiania obiektów należacych do diegezy w kontekstach przestrzennych wyraźnie wyabstrahowanych z ciagłości opowiadania. W przypadku Chtopak spotyka dziewczyne dopatrywałbym się raczej inspiracji filmowym językiem Cocteau, próby subtelnego przepisania jego estetycznej myśli na kino współczesne, a nie bezpośrednich intertekstualnych aluzji czy cytatów.

${ }^{38}$ Por. A. Zalewski, op. cit., s. 34 .

${ }^{39}$ Ibidem, s. 34.

${ }^{40}$ Ibidem, s. 35.

${ }^{41}$ Ibidem. 
wchodzi chłopak. Odczytanie tych dwóch scen jako przedstawienia tego samego wydarzenia z dwóch różnych perspektyw wydaje się uniemożliwiać ujęcie (składające się na pierwszą wersje zdarzenia), w którym stopa Aleksa (dobiegającego - należy założyć - do dziewczyny) znajduje się przez chwilę w kałuży krwi sugerującej, iż dramat rozegrał się jeszcze przed wejściem bohatera do mieszkania ${ }^{42}$. Zaakceptowanie ewentualności dwóch wariantów wprowadza jednak dodatkowa konfuzję: jaki jest stosunek obu wersji wobec siebie, która z nich rozgrywa się w porządku obiektywnym, a która jest projekcją któregoś z bohaterów? Swoista daremność interpretacji znaczeń wynikajaccych z epilogu, która można potraktować metonimicznie wobec całego tekstu, moga aprobować słowa Miczki, konstatującego za Barthes'em, iż teksty postmodernistyczne „nie podlegają w zasadzie wcześniej ustanowionym prawom i nie moga być osądzane zgodnie z określonym stanowiskiem, opartym na zastosowaniu znanych do tej pory kategorii tekstu lub dzieła”. Przytaczajac słowa francuskiego filozofa, autor Wielkiego ŻARCIA stwierdza, iż utwór z natury postmodernistyczny nie jest predestynowany do interpretowania czy opisywania pod katem semantyki, gdyż powstał z fragmentów „różnych rozbitych kodów wprowadzonych do zupełnie innego kontekstu”, dlatego też klasyczne myślenie o takich terminach, jak „znaczenie”, „treść”, „znak”, niejako się w takim tekście zaciera ${ }^{43}$.

Druga odmiana nieprzedmiotowej dezorientacji - technika demonstracyjna - dotyczy, stwierdza Zalewski, nieprzezroczystej w wymiarze formalnym prezentacji obiektów i zdarzeń zarówno konwencjonalnych i zrozumiałych, jak i tych nietuzinkowych ${ }^{44}$. Ilustracja tego drugiego zastosowania dezorientacyjnej demonstracji jest emblematyczna scena, w której po spotkaniu całującej się noca na moście pary protagonista udaje ślepca, idąc z zamkniętymi oczyma i z wyciagniętymi przed siebie rękami. Osobliwe zachowanie Aleksa, nadajace scenie wymiaru onirycznego, wydaje się komentować, docierający z warstwy dźwiękowej, utwór Davida Bowie When I Live My Dream ${ }^{45}$.

Od podtypu dezorientacji demonstracyjnej, prezentujacej zdarzenia i obiekty osobliwe, należy płynnie przejść do dezorientacji przedmiotowej poświęconej w głównej mierze właśnie niezwykłym przedmiotom czy nietuzinkowym zachowaniom postaci, przy zachowaniu względnej przejrzystości językowej. W debiutanckiej realizacji Caraksa widz doświadczy niewatpliwie wielu niecodziennych poczynań bohaterów. Do najbardziej wymownych zakłóceń na poziomie diegezy należy między innymi scena ekscentrycznego tańca Mireille w rytm Holiday in Cambodia grupy Dead Kennedys. Tytułowa bohaterka, stymulowana hardcore-punkowym utworem, obłędnie i coraz dynamiczniej kręci swa głowa, nie poruszając przy tym reszta ciała; z niepokojącego transu wytraca bohaterkę dopiero dźwięk domofonu. Kolejną ilustracją tego typu zakłóceń diegetycznych, czyli przedmiotowych, jest sekwencja w metrze rozpoczynająca się od ujęcia

\footnotetext{
${ }^{42}$ Ibidem, s. 37.

${ }^{43}$ Por. T. Miczka, op. cit., s. 94. Cyt. za J.-F. Lyotard, The Postmodern Condtion: A Report on Knowledge, Minnesota 1984, s. 84.

${ }^{44}$ Por. A. Zalewski, op. cit., s. 27-32.

${ }^{45}$ Ibidem, s. 29.
} 
przedstawiającego plakat z wizerunkiem istoty złożonej z ludzkiego korpusu i kończyn oraz z ptasiej głowy i piór wystajacych spod ubrań. Ta osobliwa hybryda, podobnie jak nieznany mężczyzna i arabski chłopiec, próbuje bezprawnie ominać wejście do głównej części metra, stanowiąc tym samym paralelę do wydarzeń, które rozegrają się za chwilę. Najpierw mężczyzna, dokonując brawurowego salta, przeskakuje bramkę, po czym tę sama sztukę - bez powodzenia - stara się powtórzyć muzułmański młodzieniec. Dodatkową konsternację odbiorczą wprowadzaja niecodziennie zachowujacy się, jakby otumanieni, pracownicy metra, którzy przymykają oko na finezyjne uchylenie się od uiszczenia opłaty w wykonaniu ekwilibrysty, natomiast w stronę wyrostka rzucają pogardliwie „Oszust!”. Najbardziej dezorientujacym zajściem tej sekwencji jest krótka scena rozgrywająca się poza przestrzenią metra: Bernard, były partner Mireille, po wybiegnięciu z budynku zatrzymuje sie przy witrynie sklepowej i wpatrując sie w jarmarczna dmuchaną kukiełkę, wykrzywia dłońmi swą twarz, tworzac grymas przerażenia przypominajacy oblicze postaci z Krzyku Edvarda Muncha. Należy jednocześnie zaznaczyć, iż nawiązanie do najsłynniejszego dzieła norweskiego ekspresjonisty jest w zasadzie drugim, po cytacie z powieści Céline’a, i ostatnim tak wyraźnym odniesieniem do innego tekstu. Debiut Caraksa, w wymiarze symptomatycznej dla omawianego paradygmatu intertekstualności, manifestuje bowiem raczej wspomniane modernistyczne zrywanie z tradycją poprzez nikłą ilość odwołań.

\section{Prymat formy}

Intertekstualne nawiązania dużo bardziej stanowia o postmodernistycznej naturze Złej krwi. Inspiracje Caraksa twórczością Godarda, wyrażone już w Chłopak spotyka dziewczyne, osiagaja tutaj pełna dojrzałość. O dziełach autora Do utraty tchu (À bout de souffle, 1960) przypomina nie tylko zamiłowanie jego postmodernistycznego epigona do filmowania postaci od tyłu, ale także obsadzenie w rolach gangsterów aktorów występujących w młodości w filmach nowofalowca. W postać gangstera Marka wcielił się Michel Piccoli znany z występu w autotematycznej Pogardzie (Le Mépris, 1963), natomiast Hans Meyer, odgrywajacy postać jego wspólnika, pojawił się w Szalonym Piotrusiu (Pierrot le Fou, 1965) - filmie skądinąd posługujacym się bardzo eklektycznym językiem, integrujacym formę nowofalową, kino gatunków oraz zabiegi właściwe sowieckiej szkole montażu. W kontekście intertekstualności interesująca jest emblematyczna dla Złej krwi scena szaleńczego biegu głównego bohatera - ponownie imieniem Alex - przez miasto. Przemieszczanie się chłopaka wzdłuż skrupulatnie dobranych fasad budynków, z równolegle podążająca zań kamera, przypomina o rozwiązaniach inscenizacyjnych wykorzystanych w Żyć własnym życiem (Vivre sa vie: Film en douze tableaux, 1962). Fragment ten jest również niezwykle znamienny dla postmodernistycznego łaczenia przekazów sztuki wysokiej z popularną. Z radiowego głośnika w pierwszej kolejności płynie utwór J'ai pas d'regret w wykonaniu Serge'a Reggianiego, kojarzonego głównie z wykonań dzieł poètes maudits (Arthura Rimbauda i Charlesa 
Baudelaire’a) oraz ze współpraca z Cocteau czy Jean-Pierre’em Melville’em, a następnie rozbrzmiewa Bowie z piosenka Modern Love. Warto nadmienić, iż aluzje do twórczości Godarda nie ujawniaja się w Złej krwi jedynie na poziomie środków wyrazowych, ale i w samej anegdocie. Historia o gangsterskim duecie werbujacym osobe trzecia do występnego planu jest odbiciem fabuły Amatorskiego gangu, w którym dwaj miłośnicy klasycznego amerykańskiego kina nakłaniaja do pomocy przy rabunku dziewczynę jednego z nich.

Nawiązania Caraksa do innych tekstów filmowych nie świadczą jednak jedynie o jego zamiłowaniu do form modernistycznych czy nowofalowych, ale również do kina klasycznego. Kilka scen w Złej krwi, że przytoczę chociaż tę z matką podejmująca zabawę w chowanego ze swym dzieckiem, do której dołącza Alex [wydarzenie spina muzyczny motyw przewodni ze Śsiatet rampy ( $\mathrm{Li}$ melight, 1952) Charlesa Chaplina], jest bowiem wyraźnie wystylizowanych na film niemy. Jednakowoż clou odniesień do tej epoki X Muzy stanowi, jak sądze, postać głównego bohatera obu filmów. Z jednej strony Denis Lavant, odgrywajacy postać Aleksa, jest aktorem niebywale cielesnym, odznaczajacym się wyczuciem kamery, zdolnym „do fenomenalnej mimiki i nieoczekiwanych zmian nastroju" ${ }^{\prime 6}$. Z drugiej - sam bohater wydaje się ucieleśniać, symptomatyczne dla kina niemego, wrażliwość, niewinność i witalność, jak i być nawiązaniem do Chaplinowskiego włóczęgi (będzie to jeszcze bardziej zauważalne w następnej realizacji Caraksa) ${ }^{47}$. Oba więc filmy (choć w większej mierze Zła krew), $\mathrm{w}$ swym postmodernistycznym kodzie, integruja niejako dwa paradygmaty kina: obraz-ruch oraz obraz-czas, zaproponowane przez Gilles'a Deleuze'a. Ten pierwszy model utożsamiał francuski filozof z filmem klasycznym wyposażonym w wykształconą strukturę narracyjna ${ }^{48}$, z przekazem przezroczystym (nazywanym przezeń organicznym), z okresem, ,kiedy filmowe obrazy były perfekcyjnie zorganizowane $\mathrm{w}$ swych geometrycznych formach, w swej przestrzenno-czasowej logice, w wypracowanych regułach montażowych, które posuwały naprzód i spajały akcje" "49. Drugi natomiast wiąże się z językiem filmowego modernizmu oraz narodzinami francuskiej Nowej Fali, oferujacych przekaz krystaliczny, w ramach którego klasyczna przyczynowo-skutkowość, sensoryczno-motoryczność zastapione zostają sytuacjami optycznymi i dźwiękowymi; motywacje bohaterów stają się pozbawione logicznej struktury wynikania; rzeczywistość często bywa oniryczna i watpliwa w swym ontologicznym statusie; natura narracji jest falsyfikująca i dezorientująca oraz zakłada niewytłumaczalne różnice

${ }^{46}$ C.-J. Malmberg, op. cit., s. 35.

${ }^{47} \mathrm{~W}$ tym kontekście warto nadmienić, że aktor odgrywający postać Aleksa wystąił w 2007 roku w filmie Harmony'ego Korine'a Pan Samotny (Mister Lonely), w którym wcielił się postać Chaplina (tudzież jego imitatora), a sam Carax wystapił gościnnie w roli impresario głównego bohatera, naśladowcy Michaela Jacksona.

${ }^{48}$ Należy zaznaczyć, że Deleuze nie utożsamia koncepcji obrazu-ruchu z kinem niemym w najwcześniejszych, najbardziej prymitywnych wydaniach, a za pierwszy film odzwierciedlajacy założenia jego teorii uznaje Sherlocka Juniora (Sherlock Jr., 1924) Bustera Keatona.

${ }^{49}$ M. Jakubowska, Gilles Deleuze (postmodernistyczna filozofia kina), [w:] Historia myśli filmowej, red. Alicja Helman, Jacek Ostaszewski, Gdańsk 2010, s. 333. 
między teraźniejszością i przeszłością; rozróżnienie między tym, co „obiektywne”, a tym, co „subiektywne”, zostaje niejako zamazane ${ }^{50}$.

O przynależności Złej krwi do nurtu postmodernizmu wysokiego (innowacyjnego - powiedziałby Zalewski), podobnie jak w przypadku dzieła debiutanckiego, świadczy duże stężenie zabiegów dezorientacji. O ile w przypadku Chłopak spotyka dziewczyne niezwykłość objawiała się, jak sądzę, głównie na poziomie diegetycznym (przedmiotowym), o tyle w kolejnej realizacji Caraksa akcent przesunął się na środki wyrazu (nieprzedmiotowość). Egzemplifikacja techniki demonstracyjnej jest sekwencja otwierajacca film, rozdzielona plansza tytułowa. W pierwszym ujęciu widz obserwuje wjeżdżający na peron pociag złożony z czerwonych tylko wagonów. W kolejnym Jean, ojciec głównego bohatera, zostaje wepchnięty na tory, a z offu dobiega jedynie dźwięk zbliżającego się pojazdu. Na zasadzie pomostu dźwiękowego odgłos pociagu towarzyszy kolejnemu ujęciu, rejestrującemu już inną przestrzeń w świecie diegezy, w którym w dużym zbliżeniu czerwona zapalniczka zbliża się do papierosa ${ }^{51}$. Posłużenie się technika match cut wywołuje wrażenie bezpośredniości i ciagłości wydarzeń, jednocześnie powodując dekoncentrację odbiorczą poprzez nienaturalne przedstawienie banalnego przedmiotu. Podobnym zbliżeniem posłużył się Carax w pierwszej scenie prezentujacej umiejętności karciane Aleksa. Karty wypełniaja kadr niemal w całości i, niezwykle szybko tasowane dłońmi głównego bohatera, tworza swoisty kolaż barw (czerwonej, niebieskiej, żółtej) powracajacych w filmie z dużą regularnością. Po chwili równie dużą przestrzeń kadru zajmuja banknoty, skrupulatnie przeliczane przez Aleksa. Detal, plan tak chętnie wykorzystywany w Złej krwi, idealnie odzwierciedla zaburzenie czytelności przestrzeni, o których pisze autor Nowej fenomenologii sensu. Rozpoczynanie kolejnej sceny od długiej rejestracji szczegółu kwestionuje zasadę ujęcia ustanawiającego, znamiennego dla klasycznego kina, oraz narusza orientacje odbiorcy w filmowej diegezie.

Przyglądajac się strategicznemu zakłócaniu procesu opowiadania, należy przywołać wpisana w środek dzieła niebywale długa (zajmujaca blisko trzydzieści minut czasu ekranowego) rozmowę protagonisty z Anna, stanowiąca narracyjna, ale i treściowa, paralelę do „powolnego trwania” sceny kuchennej Aleksa i Mireille z poprzedniego dzieła. Zalewski prototypu długich dyskusji u Caraksa upatruje - co jest zupełnie zrozumiałe - w słynnej sekwencji hotelowej z udziałem Michela i Patricii w Do utraty tchu ${ }^{52}$.

Za ilustrację ostatniej techniki, dezorientacji przedmiotowej, należy uznać między innymi nietuzinkowe zachowanie bohatera następujace w ostatniej partii sekwencji rozgrywajacej się w budynku, z którego ma zostać wykradziony wirus STBO (aluzja do AIDS). Alex, rozmawiajac przez słuchawkę z inspektorem policji, zapowiada, iż przetrzymuje zakładnika, w efekcie czego mundurowi

${ }^{50}$ Por. Małgorzata Jakubowska, Kryształy czasu: Kino Wojciecha Jerzego Hasa, Łódź 2013, s. 334-340.

${ }^{51}$ Por. A. Zalewski, op. cit., s. 28.

${ }^{52}$ Ibidem, s. 32. 
muszą zachować szczególną ostrożność. Taki rozwój sytuacji prowadzi do zaistnienia suspensu - fenomenu niespotykanego w realizacjach Caraksa. Na parterze budynku policjanci z niecierpliwością wyczekuja rozsunięcia drzwi, umożliwiającego określenie zagrożenia (konfuzja widza przewyższa tę towarzysząca stróżom prawa, gdyż jego horyzont poinformowania wykracza poza wiedze policjantów, niezdajacych sobie sprawy, iż włamywacz blefował). Niecodzienność rozwiązania całej sytuacji wynika nie tyle z przyłożenia przez Aleksa lufy rewolweru do własnej skroni, ile z faktu, iż bohaterowi udaje się wymknać w ten sposób z policyjnej zasadzki. Egzemplifikacją dezorientacji przedmiotowej jest również, jak sądzę, autotematyczny akcent, osłabiający referencyjność opowiadania. Długa rozmowa Aleksa z Anną zostaje zakłócona pojawieniem się miejscowego podglądacza za przeszklonymi drzwiami. W postać tajemniczego voyeura wcielił się sam Carax (niewątpliwie nawiązujący w ten sposób do Godarda, który często pojawiał się w niedużych epizodach w swoich realizacjach), a przeciwujęcie przedstawiające głównego bohatera zostało zorganizowane tak, aby konotować zaistnienie odbicia lustrzanego, jeszcze mocniej podkreślając funkcjonowanie Aleksa jako porte parole autora filmu.

Podobnie jak w debiucie Caraksa, intryga w Ztej krwi jest właściwie „pretekstem do cyzelowania w filmowej (zmysłowej) formie sytuacji, zdarzeń, obserwacji, których banalność tylko wnosi do nich poetycki wymiar"53. Dominanta pierwszych dzieł Francuza nie jest anegdota, ale sam styl. W Chtopak spotyka dziewczyne kuriozalne epizody koegzystuja z nieczytelna struktura narracyjna. W drugim filmie reżyser - na poziomie treści - nawiąuje wyraźniej do konwencji gatunkowych (melodramatu, kina gangsterskiego i heist film), ściagając jednak uwage z nieskomplikowanej, a przy tym tak nieczytelnej fabuły na przeestetyzowany świat przedstawiony - plastyczny rozmach, wykoncypowane scenografie, odrealnione miejsca akcji i przepych rekwizytów. W kontekście pierwszych filmów Beineiksa, najstarszego z neobarokistów, Raphaël Bassan pisze, iż anegdota uzupełniona jest „motywami pozbawionymi jakiejkolwiek funkcji, różnymi arabeskami i dygresjami, które "przeładowuja» prymarne znaczenie filmu. Przemieszcza się ono z warstwy fabularnej w strone języka wizualnego"54; słowa te można z powodzeniem odnieść do wczesnych utworów Caraksa. Realizacje neobarokowe nie neguja jednak całkowicie treści. Dzieła tercetu BBC - zauważa Bassan - poruszają zagadnienie świadomego odrzucenia, swoistego wyrzeczenia sie „ojców”. W Chtopak spotyka dziewczy$n e$ ojciec Aleksa prosi syna podczas rozmowy telefonicznej, aby go zabił, gdy będzie już niedołężny. Natomiast ojciec głównego bohatera Złej krwi ginie pod kołami pociagu już w pierwszej scenie filmu ${ }^{55}$. W dzieła te - konstatuje francuski krytyk - wpisana jest również fascynacja śmiercią dotykająca bohaterów (w pierwszym filmie umiera Mireille, w drugim - Alex $)^{56}$, będącą symptomem

\footnotetext{
${ }^{53}$ C.-J. Malmberg, op. cit., s. 35.

${ }^{54}$ Raphaël. Bassan, Filmowy neobarok (Beineix - Besson - Carax), przeł. Piotr Kopański, „Film na Świecie” 1993, nr 2 (393), s. 12.

${ }^{55}$ Ibidem, s. 16.

${ }^{56}$ Ibidem.
} 
swoistego kryzysu sztuki czy końca epoki. Obsesja ta jest zdaniem autora Wielkiego ŻARCIA główna myśla wyznaczająca wspólny mianownik treściowy dla filmów postmodernistycznych: „Niewątpliwie twórcy ci [postmodernistyczni - A.C.], a zatem również ich dzieła, mają jednak ze sobą coś wspólnego [...] wystarczy stwierdzić - kontynuuje Miczka - że fascynuje ich proces dekompozycji świata prowadzacy do śmierci wszystkich istot żywych"57.

\section{W poszukiwaniu klasycznego opowiadania}

Po pięciu latach przerwy w realizowaniu filmów Carax stworzył Kochanków z Pont-Neuf (Les amants du Pont-Neuf, 1991) - dzieło nawiąujące zarówno do poprzednich utworów Francuza, jak i do estetyki neobaroku, którego było niepisanym zamknięciem ${ }^{58}$. Pragnę zaznaczyć, że niejako na przekór obserwacjom wielu autorów piszacych o twórczości Caraksa po 1991 roku, nieufnie zapatruje się na sugestię, aby Chtopak spotyka dziewczyne, Zta krew i Kochanków z Pont-Neuf rozumieć jako trylogię. Spoiwem łączącym pierwsze trzy pełnometrażowe realizacje Francuza jest naturalnie postać Aleksa, grana każdorazowo przez Lavanta. Sam fakt, iż protagonista dwóch poprzednich filmów umiera w finale Złej krwi nie jest dla mnie nawet tak istotny (jak pisałem wcześniej, fabuła nie jest elementarnym komponentem pierwszych dzieł Caraksa), jak zauważalne różnice na poziomie formalno-estetycznym między Kochankami z Pont-Neuf a wcześniejszymi utworami, pozwalajace wpisać realizacje z 1984 i 1986 roku w ramy postmodernizmu wysokiego, a tę z roku 1991 - właściwego. Takie rozróżnienie, obierające za kryterium język, zastosowane do twórczości reżysera, który przywiązuje mniejszą wagę do zachowywania ciagłości czy logiki opowiadania, koncentrując się na estetycznym kunszcie i wizualnej efektywności, wydaje się dodatkowo adekwatne.

W pierwszej kolejności warto przyjrzeć się relacjom omawianego filmu z innymi tekstami kultury, czyli zabiegom intertekstualnym, akcentowanym coraz intensywniej z każda kolejna realizacja Francuza. Katarzyna Majewska, nawiązując do wspomnianej już typologii Genette’a, a także konstatacji Elżbiety Ostrowskiej zawartych w artykule Kino $i$ nie-rzeczywistość: O praktykach intertekstualnych we wspótczesnym filmie, stwierdza, iż najczęstszym przejawem intertekstualnej relacji jest cytat, czyli zaistnienie fragmentu bądź całości innego tekstu w dziele ${ }^{59}$. Cytaty w filmie moga być wprowadzane z uwzględnieniem „cudzysłowu”, z jego pominięciem, moga być umotywowane fabularnie lub być przedmiotem bardziej wyrafinowanych gier ${ }^{60}$. W Kochankach z Pont-Neuf pojawienie się autoportretu Rembrandta stanowi cytat malarski usprawiedliwiony

${ }^{57}$ T. Miczka, op. cit., s. 12.

${ }^{58}$ Por. Tadeusz Lubelski, Co nam dziś mówi neobarok?, „Kino” 2013, nr 7-8, s. 19.

${ }^{59}$ Por. Katarzyna Majewska, Intertekstualność $w$ filmie - odmiany i egzemplifikacje, „Studia Filmoznawcze" 1998, nr 19-21, s. 81.

${ }^{60}$ Ibidem, s. 84-85. 
diegetycznie (Hans, kloszard rezydujący na tytułowym moście, zabiera Michéle, główną bohaterkę, do muzeum, gdzie przez chwile zatrzymują się przy obrazie Holendra). Wpisanie w świat przedstawiony tekstu artysty, który zmarł w ubóstwie, tworzy paralelę do losów bezdomnej kobiety, nadając scenie rozgrywającej się $\mathrm{w}$ galerii dodatkowe znaczenie implicytne.

Inną odmianą intertekstualności jest aluzja, przejawiająca się zazwyczaj w zastosowaniu rozwiazań formalno-inscenizacyjnych przypominajacych te z dzieła "prototypowego"61. Genette zakłada, że do zrozumienia aluzyjnego nawiązania niezbędne jest dostrzeżenie związku z innym tekstem. Aluzja stwarza niekiedy konteksty semantyczne wymagające rozszyfrowania ${ }^{62}$, choć może również pełnić tylko funkcje stylizacyjne, czego przykładem jest wiele realizacji filmowego postmodernizmu. Intertekstualne aluzje moga manifestować się także na poziomie czysto diegetycznym, poprzez np. kreowanie bohaterów przypominajacych postaci z innych dzieł. Nośnikami takiej formy aluzji sa w Kochankach $z$ Pont-Neuf protagoniści, Alex i Michéle, którymi Carax odwołuje się do archetypu Pięknej i Bestii - baśni pierwotnie powstałej pod piórem Gabrielle Suzanne Barbot de Villeneauve, zekranizowanej dwa wieki później przez Cocteau - jednego z mistrzów reżysera Złej krwi. Tytułowe postaci sa nawiazaniem, zapewne jeszcze bardziej czytelnym, do innej klasycznej historii - Świateł wielkiego miasta (City Lights, 1931) Chaplina. Opowieść francuskiego reżysera, w której „włóczęga, zarabiający pluciem ogniem na bulwarach spotykał malarkę tracąca wzrok i pragną zostać «jej biała laska i psem-opiekunem»", ${ }^{63}$ silnie koresponduje z emblematycznym dla twórczości wielkiego komika bohaterem, zakochanym w niewidomej kwiaciarce - podobnie jak Michéle - odzyskującej finalnie wzrok. Alex w Kochankach... to ponownie postać wysoce cielesna, nawiąująca swymi zajęciami do sztuki cyrkowej, wykazująca się niezwykła sprawnością fizyczna i akrobatycznymi umiejętnościami. Kolejne odniesienie Caraksa do klasycznego kina niemego (w Chtopak spotyka dziewczyne miało ono charakter metatekstualnej rozmowy Aleksa z mężczyzna poznanym na przyjęciu; w Złej krwi - przywołania symptomatycznych wrażliwości dla tego kina: ruchu i dynamiczności), tym razem przybierające postać aluzji do konkretnej anegdoty (Świateł wielkiego miasta) oraz ponownego przypisania bohaterowi parametrów właściwych wczesnej twórczości Chaplina, może pełnić funkcję intertekstualnego (transtekstualnego - wypadałoby stwierdzić, skoro włączam tu koncepcję metatekstualności Genette'a) usprawiedliwienia dla nieskomplikowanych, pretekstowych fabuł.

Z nielicznych przykładów postmodernistycznej dezorientacji, tak istotnej dla stylu poprzednich dzieł Francuza, wspomnę o sposobie przedstawienia upojenia alkoholowego Aleksa i Michéle. Oko kamery otwiera scenę od szczegółowej rejestracji detali - leżącej na chodniku pustej butelki po tanim winie, papierowego kubeczka, fragmentów kostki brukowej, z offu natomiast dopływa

\footnotetext{
${ }^{61}$ Ibidem, s. 82.

${ }^{62}$ Ibidem.

${ }^{63}$ Jerzy Płażewski, Historia filmu francuskiego 1895-2003, Warszawa 2005, s. 485.
} 
infantylny śmiech bohaterów przypominajacy niemowlęce gaworzenie; po chwili protagoniści pojawiają się w kadrze, a zakłócenie (dezorientacja demonstracyjna) polega na tym, iż swoimi rozmiarami tylko w niewielkim stopniu przewyższają gabaryty wcześniej wspomnianych obiektów. Takie osobliwe przedstawienie trywialnego epizodu można jednak sfunkcjonalizować (co w przypadku dwóch wcześniejszych dzieł było przeważnie kłopotliwe), a wizerunek dwójki nietrzeźwych bohaterów wijących się w entourage'u nienaturalnie pokaźnych butelek można sprowadzić do prostej metafory przytłaczającego ich nałogu.

Dużo bardziej rozpoznawalnym elementem pozwalajacym analizować Kochanków z Pont-Neuf w optyce filmowego postmodernizmu jest nieodzowna dla tego paradygmatu heterogeniczność. Idealna egzemplifikacją dwukodowego (wielokodowego) integrowania przekazów pochodzących z różnych obszarów kultury jest imponująco zainscenizowany, będaccy pars pro toto dla postmodernistycznego eklektyzmu, szalony taniec dwójki bohaterów na moście do dźwięków „muzycznego potpourri” ${ }^{4}$, na które złożyły się melodie libańskiej wokalistki Fairouz, utwór Strong Girl Iggy'ego Popa, klasyczny walc Nad pięknym modrym Dunajem Johanna Straussa II oraz rap amerykańskiej grupy Public Enemy.

Pluralizm trzeciego filmu Francuza objawia się jednocześnie na poziomie jeszcze głębszym, bo narracyjnym. Pierwsza faza realizacji, poświęcona rozbudowanej ekspozycji bohatera, utrzymana jest w poetyce paradokumentalnej, w poszczególnych partiach (relacja z izby wytrzeźwień) porównywalnej do francuskiego skądinąd - cinéma-vérité. „Alex przyjmuje realistyczny punkt widzenia na rzeczy i ludzi. Sceny, w których jest sam na ekranie maja charakter dokumentalny, nie opowiadaja historii, lecz opisuja warunki życia paryskiego kloszarda"65. Z drugiej strony, Michéle jest postacia przypisana do drugiego sposobu rejestracji - estetyzujacej, wypełniającej rzeczywistość magicznymi obrazami i liryzmem. „Pierwsze spotkanie dwojga bohaterów [...] symbolizuje dysharmonię ich spojrzeń. Naturalistyczny obraz Aleksa leżacego na asfalcie Michéle zastępuje, dzięki swojemu malarstwu, tragicznym widmem, jakby wyjętym z «cyklu Szaleństwa» Goyi»66.

W kontekście integracji surowego realizmu z neobarokowym nadmiarem estetycznym należy przytoczyć rozważania Zalewskiego dotyczace motywacji jedności znaczacych (sensy, składniki istotne z punktu widzenia fabuły ${ }^{67}$ ) w dziele. Na przykładzie tekstów klasycznych i modernistycznych autor dokonuje rozróżnienia motywacji chwytów na przyczynowe, sekwencyjne, ramowe oraz estetyczne ${ }^{68}$. Ostatnia odmiana, tak istotna w perspektywie analizy narracji Kochanków..., „podkreśla walor sztuczności, niezwykłości wykreowanego świata”69. „Gdy wcześniejsze rodzaje [...] są wewnątrzdiegetyczne, dotycza

${ }^{64}$ Thomas Bourguignon, Miłość w Sekwanie, przeł. Piotr Kopański, „Film na Świecie” 1993, nr 2 (393), s. 39.

${ }^{65}$ Ibidem, s. 38.

${ }^{66}$ Ibidem.

${ }^{67}$ A. Zalewski, op. cit., s. 58-59.

${ }^{68}$ Ibidem, s. 62-80.

${ }^{69}$ Ibidem, s. 76. 
rzeczowej strony świata na ekranie, motywacje estetyczną tworzy suwerenny gest narracyjny uwydatniający samą czynność opowiadania"70. Innymi słowy, kategorie umotywowania znaczeń w dziele filmowym stosuje polski filmoznawca do „wiarygodności” relacji pomiędzy składnikami istotnymi dla fabuły a środkami wyrazu.

Podobnie jak omówione wyżej osobliwe przedstawienie alkoholowego upojenia dwójki bohaterów, stylistyczna dychotomię można - bez nadużyć interpretacyjnych - zracjonalizować, a więc ja umotywować w oparciu o treść. $\mathrm{O}$ protagonistach i ich skontrastowanych sposobach percypowania otoczenia (symbolicznie przedstawionych $\mathrm{w}$ scenie przejażdżki na diabelskim młynie, w której mężczyzna spuszcza głowę i zasłania oczy, a kobieta napawa się ekscytujaccymi widokami) trafnie pisze Thomas Bourguignon: „W przeciwieństwie do Michéle, która pogarszający się wzrok stopniowo pogrąża w kompletnej ciemności, Alex nie może spać, jego oczy musza być nieustannie otwarte na brzydotę świata i własną bezsilność"

Po znikającym z jej [Michéle - A.C.] oczu świecie wodzi ona bolesnym i namiętnym spojrzeniem, które wszystko uwzniośla. Dzięki niemu powszedniość staje się fantastyczna. Cudowne sekwencje obchodów dwóchsetlecia rewolucji nie są zatem pozbawione motywacji, lecz ilustruja jej pragnienie zachłyśnięcia się najbardziej upajającymi obrazami, zanim po święcie światła wygasną ${ }^{72}$.

W tym miejscu warto przypomnieć fundamentalne założenie Zalewskiego w Strategicznej dezorientacji, utożsamiające kino postmodernistyczne innowacyjnego nurtu z koncepcja zmiany dewiacyjnej (dotyczącej w szerokim znaczeniu podniesienia dezorientacji z poziomu techniki na poziom strategii; w znaczeniu węższym - filmowych elementów niespójnych z fabularnym bądź wizualnym kontekstem). Autor jednocześnie podkreśla, iż zaistnienie efektu dewiacyjnej zmiany jest możliwe dzięki zastosowaniu motywacji ujemnej, czyli zanegowaniu - przez tekst postmodernistyczny - przywołanych powyżej motywacji ${ }^{73}$. Konkluzja powyższych obserwacji nie ma być oczywiście zakwestionowanie przynależności omawianego filmu do kina postmodernistycznego, ale zaakcentowanie niemożności wpisania go do tzw. nurtu innowacyjnego (wysokiego - powołując się na typologię Lewickiego) oraz zwrócenie uwagi na zasadnicze różnice pomiędzy Kochankami $z$ Pont-Neuf a poprzednimi dziełami Francuza. Filmem, w którym gatunkowa heterogeniczność zostaje - niczym odmienne światy Aleksa i Michéle - pogodzona w finale, Carax dokonał zauważalnej zmiany w artystycznej orientacji. Chtopak spotyka dziewczyne oraz Zła krew sa dziełami w dużej mierze nieprzezroczystymi narracyjnie, o dużym stężeniu formalnych i treściowych zakłóceń, głęboko nawiązującymi do stylu opowiadania właściwego rodzimemu kinu modernistycznemu. Natomiast Kochankowie $z$ Pont-Neuf to realizacja dużo bardziej powściagliwa językowo,

\footnotetext{
${ }^{70}$ Ibidem.

${ }^{71}$ T. Bourguignon, op. cit., s. 38.

${ }^{72}$ Ibidem.

${ }^{73}$ Por. A. Zalewski, op. cit., s. 50-58.
} 
oferująca większą komunikatywność zabiegów estetyzujących diegezę, a także - czytelność treściowa, zarówno na poziomie psychologii bohaterów, jak i przyczynowo-skutkowej logiki zdarzeń.

\section{Spóźniony manifest filmowego postmodernizmu}

O postmodernistycznej proweniencji Holy Motors (2012), ostatniego dotąd filmu Francuza, jeszcze wyraźniej niż w przypadku Kochanków z Pont-Neuf, świadcza inklinacje do nawiązań intertekstualnych. Te najbardziej czytelne wprowadzone zostały, jak sądzę, w segment poświęcony panu Merde, jednej z wielu inkarnacji Oscara, głównego bohatera. W scenie pochodu groteskowej postaci przez cmentarz Père-Lachaise w niediegetycznej warstwie dźwiękowej reżyser wykorzystał, na zasadzie cytatu, muzyczny motyw przewodni, autorstwa Akiry Ifukube, z Godzilli (Gojira, 1954) Ishirô Hondy. Karykaturalne wcielenie Oscara, podobnie jak gigantyczny „król potworów” zrodzony w wytwórni Tōhō, sieje chaos i spustoszenie na ulicach wielkiego miasta. Merde zatrzymuje się finalnie w pobliżu odbywajacej się na cmentarzu sesji zdjęciowej, aby przez chwilę napawać się uroda Kay M, w stronę której natchniony fotograf z dużą regularnością rzuca: „Piękna!”. W tym miejscu widz przypomni sobie nie tylko o, przywoływanej już w Kochankach..., historii Pięknej i Bestii, ale i - za sprawą wątku uprowadzenia modelki - o King Kongu (1933) Meriana C. Coopera i Ernesta B. Schoedsacka, w którym tytułowa istota porywa piękna Ann na wyspę.

Jeszcze inną aluzja jest scena relacjonujaca wspólnie spędzone chwile przez Oscara, głównego bohatera, i Jean, jego dawną ukochaną. Epizod kończy się tragiczna śmiercia kobiety po skoku z dachu wysokiego hotelu Samaritaine. Owo spotkanie, którego clou stanowia słowa piosenki śpiewanej przez Jean: „Kim jesteśmy? Kim byliśmy? Kim byliśmy, gdy byliśmy, kim byliśmy?”, przywodzi na myśl zakończenie Zawrotu głowy (Vertigo, 1958), dzieła opowiadającego zarówno o problemie tożsamości, jak i o wcielaniu się w postać drugiej osoby. Nawet strój bohaterki Holy Motors (niebieska garsonka) przypomina emblematyczna, i tak istotna dla protagonisty filmu Hitchcocka, kreacje Madeleine. Natomiast uczesanie Céline, kierowcy limuzyny, jest łudzaco podobne do fryzury postaci granej przez Kim Novak - kolejnego w oczach „Scottiego” Fergusona nieodzownego przymiotu utęsknionej kobiety.

Godne uwagi jest aluzyjne napięcie dotyczace postaci granej przez Edith Scob. Majewska w tekście o intertekstualności, powołując się na obserwacje Ostrowskiej, pisze, iż w potocznym odbiorze tekstów filmowych widz nierzadko utożsamiał bohaterów fikcyjnych z aktorami wcielającymi się w ich role. Natomiast współcześnie bardzo często zachodzi sytuacja odwrotna - to aktor bywa nieodzownie związany w oczach odbiorcy z rolą ${ }^{74}$. Céline, odgrywana przez wspomniana francuską aktorkę, wśród rodzimej widowni znaną przede wszystkim

${ }^{74}$ Por. K. Majewska, op. cit., s. 83. 
z kreacji w obrazie Oczy bez twarzy (Les Yeux sans visage, 1960), w finale utworu Caraksa nakłada, na krótką chwilę, na twarz zieloną maskę, do złudzenia przypominająca atrybut bohaterki filmu Georges'a Franju, korespondujac w ten sposób - na zasadzie ironicznego odniesienia - z emploi Scob. Nawiązanie do dzieła twórcy Krwi zwierzat (Le Sang des bêtes, 1949) można również interpretować jako powołanie się na tekst podszyty zagadnieniem zagrożonej tożsamości, mający wyznaczyć perspektywę znaczeń budowanych przez autora Kochanków z Pont-Neuf. Aluzji i cytatów w ostatniej realizacji Francuza nie ograniczałbym jednak tylko do konkretnych tekstów „prototypowych” - należy je, jak sądze, metonimicznie zaprojektować na całe gatunki, konwencje, filmowe archetypy. „Oprócz [...] dwóch potencjalnych dramatów rodzinnych mamy do czynienia z rasowym musicalem, pełnokrwistym (dosłownie) azjatyckim kinem akcji, quasi-ekranizacja nieistniejacej powieści Henry'ego Jamesa czy filmem fantasy, zakończonym muzułmańską wariacją na temat Piety"75.

Znamiona omawianego systemu sygnifikacji nie ograniczaja się w Holy Motors jedynie do poziomu kinofilskich aluzji, intertekstualnego przetwarzania i hołdowania wielkim archetypom X Muzy. Postmodernistyczny rodowód tejże realizacji sięga do (najprawdopodobniej) świadomych adaptacji myśli teoretyków interesującego mnie zjawiska, Jamesona i Deleuze'a. Ten ostatni, w ramach postmodernistycznej filozofii kina, zaproponował koncepcję nomadologii. Francuz, kwestionując dyktat rozumu wyprowadzony z myśli platońskiej, postulował o „nowy, wolny sposób filozofowania”76. Opozycją dla osiadłego systemu myślowego, charakteryzującego się dążeniem do całościowego ujęcia, zamknięciem świata w jasno wyznaczonych zbiorach i regułach, jest według Deleuze'a myślenie nieskrępowane, do którego opisania posłużył się metaforą nomadycznego trybu życia ${ }^{77}$. Modelowym uosobieniem postmodernistycznego wędrowca jest w dziele Caraksa postać pana Oscara, wraz ze swoimi wieloma inkarnacjami, przemierzająca ulice otępiałego Paryża. „[...] Od sytego ojca rodziny przez stara żebraczkę i odrażające monstrum po groteskowego ojca - Lavant gra kogoś w rodzaju człowieka uniwersalnego, człowieka-wiązkę nieograniczonych możliwości"78 - pisze o Holy Motors Lubelski. Obaj Francuzi, filozof i filmowiec, kontestuja bezpieczne struktury i utarte reguły, Deleuze - myślenia, Carax - opowiadania. To niepisane przymierze postmodernistów symbolicznie, bo na poziomie filmowej diegezy, wyraża w omawianej realizacji postać wędrowca, pana Oscara, za charakterystykę którego mogłyby posłużyć słowa Małgorzaty Jakubowskiej, interpretującej Deleuze'owską nomadologię:

Nomada w przeciwieństwie do osiedleńca nie tylko sam jest wędrowcem, będącym w ciągłym ruchu, ale żyje, mając świadomość zmienności krajobrazu, który go otacza. Jego przestrzeń pozostaje otwarta, nie tylko może w każdej chwili zostać poszerzona lub zmieniona, ale jest stawaniem się. Świat nomady oparty jest na równorzędności elementów, nie zawiera

\footnotetext{
${ }^{75}$ Ewa Szponar, „Holy Motors”: elegia o ruchu, „EKRANy” 2012, nr 6, s. 46.

${ }^{76}$ M. Jakubowska, Gilles Deleuze..., s. 331.

${ }^{77}$ Ibidem, s. 331-332.

${ }^{78}$ T. Lubelski, op. cit., s. 21.
} 
uprzywilejowanej części w postaci centrum, jest kwintesencją wieloośrodkowości, nie ma początku ani końca, nie ma granic, sam teren znajduje się w ciagłym odtwarzaniu i przetwarzaniu. Nomada docenia różnorodność świata, nie musi panować nad bytem, jest bowiem jego częścią, wraz z nim może się zmieniać ${ }^{79}$.

Wielopostaciowość głównego bohatera konotuje, poza koncepcjami autora Różnicy i powtórzenia, wzmiankowany już wcześniej kryzys tożsamości indywidualnej utożsamiany przez Jamesona z kresem modernizmu. Amerykanin, w eseju traktującym o społeczeństwie w dobie ponowoczesności, przytacza dwie perspektywy rozważań nad autonomicznym podmiotem. Przypomnę, pierwsza zakłada, iż jest on konceptem przebrzmiałym, druga, że jest jedynie mitem. Oba stanowiska sa jednak zgodne wobec tego, iż indywidualna niepowtarzalność w ponowoczesności nie istnieje ${ }^{80}$.

W obszar implicytnie problematyzowanych zagadnień znamiennych dla postmodernizmu właczył również Carax kazus wyczerpania i poczucia końca sztuki, symbolicznie ujętego w dialogu pomiędzy głównym bohaterem a jego tajemniczym zwierzchnikiem:

Mężczyzna: Co sprawia, że dalej to robisz, Oscarze?

Pan Oscar: To samo, co sprawiło, że zacząłem: piękno tego aktu.

Mężczyzna: Piękno? Mówi się, że piękno leży w oku patrzącego.

Pan Oscar: A co kiedy zabraknie patrzacego?

Znamienne dla postaci granej przez Lavanta, rozpaczliwie pragnacej „przeżyć te same rzeczy na nowo"81, wyczerpanej kultura nadmiaru, wcielającej się w kolejne jednostki nawiązujace do gatunkowych konwencji i kanonu kina, okazują się również słowa Jamesona:

[...] w świecie, w którym innowacja jest niemożliwa, pozostało jedynie naśladować martwe style, zakładać językowe maski, mówić głosami z muzeum wyobraźni. Oznacza to jednak, że współczesna czy też postmodernistyczna sztuka będzie mówiła o sztuce samej w jakiś nowy sposób; co więcej, oznacza to, że jej podstawowe przesłanie wiązać się będzie z nieuniknioną klęską sztuki i estetyki, z klęską „nowego”, z uwięzieniem w przeszłości ${ }^{82}$.

Holy Motors, podobnie jak Kochankowie z Pont-Neuf, odwołuja się w dużej mierze do filmu popularnego, jednocześnie przekraczajac jego schematy. Zdaniem autora Sztucznych światów, teksty „właściwie” postmodernistyczne dopuszczaja odbiór niezobowiązujący, a zarazem wymagaja od widza kompetencji, obycia z kinem pozwalającego odczytać intertekstualne napięcia czy zrozumieć stylistyczna heterogeniczność. Przyjmując jako punkt odniesienia filmy Chtopak spotyka dziewczyne i Zta krew, tak silnie nawiązujace do kodów modernistycznych, należy stwierdzić, że późniejsze utwory Caraksa znamionuje większa dynamiczność i przezroczystość narracyjna, służebność zabiegów estetyzujących oraz aluzji i cytatów wobec treści, a także przystępność aspektów fabularnych.

\footnotetext{
${ }^{79}$ M. Jakubowska, Gilles Deleuze..., s. 332.

${ }^{80}$ Por. F. Jameson, op. cit., s. 196.

${ }^{81}$ Słowa piosenki Gérarda Manseta Revivre, puentującej Holy Motors.

${ }^{82}$ F. Jameson, op. cit., s. 197.
} 


\section{Bibliografia}

Bassan R., Filmowy neobarok (Beineix - Besson - Carax), przeł. P. Kopański, „Film na Świecie” 1993, $\mathrm{nr} 2$ (393).

Bourguignon Th., Mitość w Sekwanie, przeł. P. Kopański, „Film na Świecie” 1993, nr 2 (393).

Céline L.-F., Śmierć na kredyt, Wydawnictwo Zielona Sowa, Kraków 2004.

Drzał-Sierocka A., Luc Besson: Uśmiechnięta twarz filmowego postmodernizmu, Wydawnictwo Akademickie Sedno, Warszawa 2012.

Genette G., Palimpsesty. Literatura drugiego stopnia, przeł. A. Milecki, [w:] Wspótczesna teoria badań literackich za granica, red. H. Markiewicz, t. 4, cz. 2, Kraków 1992.

Hassan I., Toward a Concept of Postmodernism, [w:] The Postmodern Turn: Essays in Postmodern Theory and Culture, ed. I. Hassan, Ohio State University Press, Columbus 1987.

Jakubowska M., Gilles Deleuze (postmodernistyczna filozofia kina), [w:] Historia myśli filmowej, red. A. Helman, J. Ostaszewski, Wydawnictwo słowo/obraz terytoria, Gdańsk 2010.

Jakubowska M., Krysztaty czasu: Kino Wojciecha Jerzego Hasa, Wydawnictwo Uniwersytetu Łódzkiego, Łódź 2013, s. 334-340.

Jameson F., Postmodernizm i społeczeństwo konsumpcyjne, przeł. P. Czapliński, [w:] Postmodernizm. Antologia przekładów, red. R. Nycz, Baran i Suszczyński, Kraków 1996.

Lewicki A., Sztuczne światy: Postmodernizm $w$ filmie fabularnym, Wydawnictwo Uniwersytetu Wrocławskiego, Wrocław 2007.

Lubelski T., Co nam dziś mówi neobarok?, „Kino” 2013, nr 7-8.

Lyotard J.-F., Odpowiedź na pytanie: co to jest postmodernizm, przeł. M. P. Markowski, [w:] Postmodernizm. Antologia przekładów, red. R. Nycz, Baran i Suszczyński, Kraków 1996.

Majewska K., Intertekstualność w filmie - odmiany i egzemplifikacje, „Studia Filmoznawcze” 1998, nr 19-21.

Malmberg C.-J., Miłość od ostatniego spojrzenia, przeł. P. Kopański, „Film na Świecie” 1993, nr 2 (393).

Miczka T., Wielkie ŻARCIE i POSTmodernizm: o grach intertekstualnych w kinie wspótczesnym, Wydawnictwo Uniwersytetu Ślaskiego, Katowice 1992.

Morawski S., Ktopoty z postmodernizmem, „Kino” 1991, nr 2.

Morawski S., Postmodernizm a kultura filmowa, „Kino” 1991, nr 3.

Nycz R., Tekstowy świat. Poststrukturalizm a wiedza o literaturze, Wydawnictwo Universitas, Kraków 2000.

Oramus D., O pomieszaniu gatunków: science fiction a postmodernizm, Wydawnictwo Trio, Warszawa 2010.

Płażewski J., Historia filmu francuskiego 1895-2003, Wydawnictwo Auriga, Warszawa 2005.

Szponar E., „Holy Motors”: elegia o ruchu, „EKRANy” 2012, nr 6.

Zalewski A., Strategiczna dezorientacja: Perypetie rozumu $w$ fabularnym filmie postmodernistycznym, Ośrodek Wydawniczo-Poligraficzny SIMP, Warszawa 1998.

Żmigrodzki P., Wprowadzenie do leksykografii polskiej, Wydawnictwo Uniwersytetu Ślaskiego, Katowice 2003. 